\title{
Immunomodulatory Activity of Methanolic Extracts of Ficus Glomerata Roxb. Leaf, Fruit and Bark in Cyclophosphamide Induced Mice
}

\author{
Sanjeev Heroor ${ }^{1, *}$, Arunkumar Beknal ${ }^{1}$, Nitin Mahurkar ${ }^{2}$ \\ ${ }^{1}$ Dept. of Pharmacogonsy and Phytochemistry, HKES's MTR institute of Pharmaceutical Sciences, Gulbarga, Karnataka, India \\ ${ }^{2}$ Dept. of Pharmacology, HKES's MTR institute of Pharmaceutical Sciences, Gulbarga, Karnataka, India
}

\begin{abstract}
To evaluate the immunomodulatory activity of methanolic extracts of Ficus glomerata Roxb. leaves, fruits and bark on cyclophosphamide induced immunosuppression in mice. Methanolic extracts of leaves, fruits and bark of Ficus glomerata Roxb. (500mg/kg p.o.) were administered 13 days to albino mice and cyclophosphamide ( $30 \mathrm{mg} / \mathrm{kg}$ i.p.) was administered on 11th,12th and 13th days 1 hour after the administration of the respective treatment. On the 14th day blood was collected by retro orbital puncture and the activity was evaluated by determining the $\mathrm{RBC}, \mathrm{Hb} \%$, Platelet, total $\mathrm{WBC}$ and differential counts. Methanolic extracts of leaves, fruits \& bark of Ficus glomerata Roxb. showed very significant $(\mathrm{p}<0.001)$ counteracting effect to cyclophosphamide induced reduction in total WBC, DLC and platelet counts \& significant $(\mathrm{P}<0.01)$ effect to that of reduction in $\mathrm{RBC}$ counts and $\mathrm{Hb} \%$. The significant inmmunostimulant effect of the methanolic extracts of Ficus glomerata Roxb. leaf, fruit \& barks on cyclophosphamide induced myelosuppression may be attributed towards the collective presence of saponins, sterols and tannins in the extracts, which suggest the immunomodulatory activities of the methanolic extracts of Ficus glomerata Roxb. leaves, fruits \& bark.
\end{abstract}

Keywords Ficus Glomerata Roxb, Cyclophosphamide, Immunomodulatory, Myelosuppression

\section{Introduction}

Indian traditional systems of medicine like Siddha and Ayurveda have suggested to increase the body's natural resistance to disease under the concept of 'Rasayana'. A number of medicinal plants as Rasayanas such as Tinospora codifolia, Mangifera indica, etc. have been claimed to possess immunomodulatory activity[1]. Immunomodulation is any procedure which can alter the immune system of an organism by suppression and stimulation of the cells and organs of the immune system[2].

Immunostimulation in a drug induced immunosuppression model and immuno suppression in an experimental hyper-reactivity model by the same preparation can be said to be true immunomodulation[3]. Certain agents have been shown to possess acitivity to normalize or modulate pathophysiological processes and hence are called immunomodulatory agents[4]. A number of medicinal plants have been screened systematically for their immunomodulatory activity such as Tinospara cordifolia, Mangifera indica[5]. Cyclophosphamide is an alkylating agent widely used in

* Corresponding author:

ssheroor@gmail.com (Sanjeev Heroor)

Published online at http://journal.sapub.org/ijmb

Copyright (C) 2011 Scientific \& Academic Publishing. All Rights Reserved anti-neoplastic therapy. It is effective against a variety of cancers such as lymphoma, myeloma and chronic lymphocytic leukemia[6]. Cyclosphamide acts on both cyclic and intemitotic cells, resulting in general depletion of immune competant cells[7]. Cyclophosphamide induced immunosuppression is reported to prompt various types of infections[8].

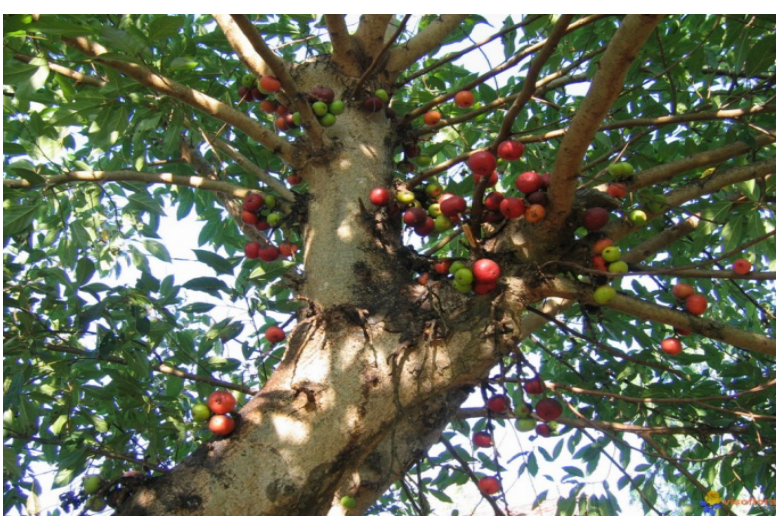

Figure 1. Image of the plant of Ficus glomerata Roxb

(Figure 1) Ficus glomerata Roxb. (Syn. Ficus racemosa) family: moraceae, an evergreen tree of $15-18 \mathrm{~m}$ height. Young shoots are glabrous, pubescent with ovate and tapering leaves. The tree bears a few aerial roots, figs pubescent, reddish when ripened[9]. Survey of literature shows 
the presence of glycosides, tannins and wax[10]. Traditionally leaves are used in bilious affection and diarrhea. Fruit is edible and is given in menorrhagia, haemoptysis and in diabetes. Bark is used in the form of fine powder in dysentery, diabetes and in combination with gingelly oil it is applied to cancerous affections[11]. The present study was aimed at screening of methanolic extracts of leaves, fruits and bark Ficus glomerata Roxb. for immunomodulatory activity on cyclophosphamide induced immune suppressed albino mice.

\section{Materials \& Methods}

\subsection{Plant Material}

Leaves, fruits and bark of Ficus glomerata Roxb. were collected from local areas of North Karnataka \& a voucher specimen has been deposited at the departmental herbarium. The mentioned parts of the plant were dried and pulverized to particle size (\#) 40 and then were first defatted with petroleum ether (40-600C) and extracted with methanol using Soxhlet apparatus for $48 \mathrm{~h}$ to obtain methanolic extracts of leaves, fruits and barks of the plant respectively. The filtrates of the extracts were concentrated to dryness at $40^{\circ} \mathrm{C}$ under reduced pressure in a rota evaporator.

The yields of the methanolic extracts of leaves, fruits and barks were $23.97 \mathrm{gm}(14.47 \% \mathrm{w} / \mathrm{w}), 9.95 \mathrm{gm}(9.25 \% \mathrm{w} / \mathrm{w})$ and $52.85 \mathrm{gm}(33.02 \% \mathrm{w} / \mathrm{w})$ respectively.

\subsection{Preliminary Phytochemical Studies}

The phytochemical screening and TLC studies[12,13] of the methanolic extracts of leaves, fruits and barks indicated the presence of carbohydrates, glycosides, wax, steroids, saponins and tannins but only the fruit extract showed the presence of proteins instead of wax.

\subsection{Animals}

Swiss albino mice of either sex, weighing $25-30 \mathrm{~g}$ household in standard conditions of temperature, humidity and light were used. They were fed with standard rodent diet and water ad libitum.

\subsection{Acute Toxicity Studies}

Acute toxicity studies were conducted as per OECD guideline by 425 method to assess LD50[14]. The animals did not show mortality at the dose of $5000 \mathrm{mg} / \mathrm{kg}$ and hence its $1 / 10$ th dose i.e., $500 \mathrm{mg} / \mathrm{kg}$ was used as the therapeutic dose for the methanolic extracts of the study.

\subsection{Test Samples}

Weighed quantities of test extracts were suspended in 1\% sodium carboxy methyl cellulose to prepare a suitable dosage form[15]. The control animals were given an equivalent volume of sodium $\mathrm{CMC}$ vehicle.

\subsection{Drugs}

Cyclophosphamide was used as a standard immunosuppressant, Cycloxan ${ }^{\circledR}$ (Biochem - pharmaceutical industries Ltd. Mumbai) containing 200mg - cyclosphosphamide, was procured from the market and dilutions were made using sterile water for injection as mentioned on the label of the marketed product.

\subsection{Cyclophosphamide Induced Myelosuppression[16]}

Animals were divided into four groups of six animals each. Group I served as Control group, received the vehicle( $1 \%$ sodium CMC) for a period of 13 days. Group II (Cyclophosphamide group) received the vehicle ( $1 \%$ sodium $\mathrm{CMC}$ ) for a period of 13 days and on $11^{\text {th }}, 12^{\text {th }}$ and $13^{\text {th }}$ days was injected with cyclophosphamide $(30 \mathrm{mg} / \mathrm{kg}$ i.p). Group III, IV and V were administered methanolic extracts of leaves, fruits and bark of the plant $(500 \mathrm{mg} / \mathrm{kg}$ p.o.) daily for 13 days. The animals of groups III, IV and V were injected with Cyclophosphamide (30mg/kg i.p) on the 11th, 12th \& 13th days, 1 hour after the administration of the respective treatment. Blood samples were collected on the 14th day of experiment by retro orbital puncture and hematological parameters were studied for $\mathrm{RBC}, \mathrm{Hb} \%$, Platelets, total WBC counts and differential leucocytes counts (DLC).

Statistical analysis:Data were expressed as mean \pm SEM and differences between the groups were statistically determined by analysis of variance followed by Dunnet's test.

\section{Results and Discussions}

Cyclophosphamide at the dose of $30 \mathrm{mg} / \mathrm{kg}$. i.p. caused a significant reduction in total WBC count, differential leucocyte counts and platetes and to some extent reduction in $\mathrm{RBC} \& \mathrm{HB} \%$ as compared to control group (Group I). Methanolic extracts of leaves, fruits and bark showed very significant $(\mathrm{P}<0.001)$ increase in total $\mathrm{WBC}, \mathrm{DLC}$ and Platelets and significant $(\mathrm{P}<0.01)$ increase in $\mathrm{RBC}$ and $\mathrm{Hb} \%$ when compared with cyclophosphamide group (Group II). However the significant effects of fruits and bark extracts of methanol were more pronounced than that of the methanolic extract of leaves.

Table 1. Effect of methanolic extracts of Ficus glomerata Roxb. leaf, fruit and barks on cyclophosphamide induced myelosuppression

\begin{tabular}{ccccc}
\hline Animal group $\mathrm{n}=6$ & $\mathrm{RBC}(106 / \mathrm{mm} 3)$ & $\mathrm{Hb}(\mathrm{g} \%)$ & Platelets $(105 / \mathrm{mm} 3)$ & WBC $(103 / \mathrm{mm} 3)$ \\
\hline I & $6.332 \pm 0.060$ & $9.667 \pm 0.076$ & $6.467 \pm 0.071$ & $4.550 \pm 0.133$ \\
II & $5.047 \pm 0.090$ & $8.100 \pm 0.118$ & $4.783 \pm 0.047$ & $2.300 \pm 0.208$ \\
III & $5.728^{*} \pm 0.148$ & $9.133^{*} \pm 0.105$ & $5.700^{* *} \pm 0.129$ & $3.250^{* *} \pm 0.076$ \\
IV & $5.777^{*} \pm 0.127$ & $9.150^{*} \pm 0.056$ & $5.717 * \pm 0.130$ & $3.150^{*} \pm 0.160$ \\
V & $5.748^{*} \pm 0.127$ & $9.217^{*} \pm 0.090$ & $5.750^{* *} \pm 0.128$ & $3.700^{* *} \pm 0.077$ \\
\hline
\end{tabular}


Table 2. Effect of methanolic extracts of Ficus glomerata Roxb. leaf, fruit and Barks on cyclophosphamide induced myelosuppression

\begin{tabular}{cccccc}
\hline Animal Gr. $\mathrm{n}=6$ & Neutrophils (\%) & Lymphocytes (\%) & Eosinophils (\%) & Basophils (\%) & Monocytes (\%) \\
\hline I & $22.83 \pm 0.600$ & $73.50 \pm 0.428$ & $2.667 \pm 0.210$ & $1.667 \pm 0.210$ & $1.667 \pm 0.210$ \\
II & $12.50 \pm 0.562$ & $64.00 \pm 0.730$ & $0.666 \pm 0.210$ & $0.333 \pm 0.210$ & $0.166 \pm 0.167$ \\
III & $16.50^{* *} \pm 0.619$ & $69.83^{*} \pm 0.477$ & $1.500^{*} \pm 0.223$ & $0.500^{*} \pm 0.223$ & $0.666^{*} \pm 0.210$ \\
IV & $15.83 *^{* * \pm 0} 0.307$ & $69.17^{* * \pm 0.749}$ & $1.333^{* * \pm 0} \pm 0.210$ & $0.333^{* * \pm 0} \pm .210$ & $0.500^{*} \pm 0.223$ \\
V & $16.50^{* * \pm} \pm 0.428$ & $69.33^{* * \pm 0.802}$ & $1.500^{*} \pm 0.223$ & $0.500^{* * \pm 0} \pm 0.223$ & $0.666^{*} \pm 0.210$ \\
\hline
\end{tabular}

Immunomodulatory activity of methanolic extract of leaves, fruits and bark of Ficus glomerata Roxb. was explored by evaluating their effects on cyclophosphamide induced myelosuppression in mice. Results of the study revealed the counteracting effect of the extracts to the cyclophosphamide induced bone marrow activity suppression i.e. myelosuppression, as indicated by increase in RBC, total WBC platelet counts, $\mathrm{Hb} \%$ and DLC in the extract treated groups (Group III \& IV), when compared to cyclophosphamide treated group (Group II).

Bone marrow is a site of continued proliferation and turnover of blood cells and is also a source of cells involved in immune activity. A high degree of cell proliferation renders bone marrow a sensitive agent, particularly to cytotoxic drugs. In fact bone marrow is the organ most affected during any immunosuppression therapy with this class of drugs. Loss of stem cells and inability of bone marrow to regenerate new blood cells will result in thrombocytopenia and leucopenia[17].

The results indicate modulation of bone marrow activity, namely - suppression when used cyclophosphamide alone and stimulation to counteract the cyclophosphamide induced myelosuppression in pretreated methanolic extract groups of leaves, fruits and bark of Ficus glomerata Roxb.

\section{Conclusions}

From the phytochemical investigation, it was found that the major chemical constituents of the methanolic extracts of leaves, fruits and bark were steroids, saponins, tannins, proteins and carbohydrates. Saponins are either triterpenoid or steroidal glycosides proven as important phytoconstituent with different pharmacological activities such as antiallergic, cytotoxic, antitumour, antiviral, immunomodulating, antihepatotoxic, and antifungal activities. Recently three diosgenyl saponins isolated from Paris polyphylla reported for immunostimulating activity[18]. Tannins are also known to possess immunostimulating activites. The well known ayurvedic formulation, Triphala Churna contains Terminalia chebula, Terminalia belenica and Emblica officialis, which are rich in tannins have been reported for immunostimulating activity[19]. Hence the collective presence of steroids, saponins and tannins in the methanolic extracts would be attributed for immunostimulating activity. However methanolic extracts of fruits and bark of Ficus glomerata Roxb. exhibited more immune-potentiating activity than that of methanolic extract of leaves. Further studies are underway to find out the exact mechanism of immunostimulating effect of
Ficus glomerata Roxb.

\section{ACKNOWLEDGEMENTS}

Authors are thankful to authorities of HKESociety and MTR Institute of Pharmaceutical sciences, Gulbarga, Karnataka India, for providing necessary facilities to carry out the study.

\section{REFERENCES}

[1] Charak Samhita (Trans.), Shree Gulab Kunvera Ayurvedic Society, Jamnagar, India, 1949

[2] A.R. Bafna, Mishra S.H, Immunostimulatory effect of methanol extract of Curculigo orchioides on immunosuppressed mice, J. Ethnopharmacol.,2 006, 104:1-4

[3] B Patwardhan, D Kalbag, P.S. Patki, B.A. Nagasampagi, Search of Immunomodulatory agents: a review, Indian Drugs, 1990, 28 (2), 56-63

[4] H. Wagner, Immunomodulatory agents. Proceedings of the Alfred Benzon Symposium, Vol 20, 1983, p. 559

[5] N Makare, S. Bodhankar, V. Rangari, Immunomodulatory activity of alcoholic extracts of Mangifera indica Linn. in mice, J. Ethnopharmacol., 2001,78:133-137

[6] F Baumann, R Preiss, Cyclophosphamide and related anticancer drugs, B. chrmoatogr. B, Biomed Sci. Appl., 764:173-192

[7] J. W. Goodman, D.P. Stites, A. I. Terr., T.G. Parslow (Eds.), The Immune response in Basic and Clinical Immunology, 8th Edn. Prentice-Hall, Engle wood Cliffs, NJ, 1994, 40-47

[8] I. Angulo, M. B. Jimenez, J.F. Garcia Bustos, D. Gargallo, Candida albicans infection enhances immunosuppression induced by cyclophosphamide by selective priming of suppressive myeloid progenitors, cell immunol,, 2002,218:46-58

[9] J C Kurian. Plants that heal, Orientale Watchman Publishing House, Pune, vol. I, 1998, p.159

[10] K.M. Nadkarni, Indian Materia Medica, Popular Prakashan, vol I, 1996, 548-550

[11] P.S. Variar's, Indian Medicinal Plants, a compendium of 500 species, Orient Longman Ltd., Madras, vol. III, 1994, p.34

[12] K.R. Khandelwal, Practical Pharmocognosy Techniques and Experiments, 10th Ed., Nirali Prakashan, Pune, 2003,149 158

[13] Hildebert Wagner, Sabine Bladt, Plant Drug Analysis-A Thin layer Chomoatography Atlas, Springer-verlag. Berlin Hei- 
delberg, New York, 2nd Ed., 2001;1-3, 195-197, 305-206

[14] Committee for the purpose of control and supervision of Experimental Animals(CPCSEA), OECD Guidelines for the testing of Chemicals, revised draft guidelines 425: Acute oral toxicity-Acute toxic class method, revised document. India: Ministry of Social Justice and Empowerment;2000

[15] K.L Satpute, M.M. Jadhav, R.S. Karodi, M.J. Patil, Immunomodulatory activity of fruits of Randia dumetorum Lamk., J. Pharmocog. \& Phytother., Vol. 1, 2009, p. 1-5

[16] P.N. Manjarekar, C.L. Jolly, S. Narayan, Comparative studies of immunomodulatory activity of Tinospora cordifolia \& Tinopora sinensis,Fitoterpia,2001, 71:254-257
[17] M.J. Pelczar, E.C.S. Chan, N.R. Krieg, Microbiology, 5th Ed., Tata Mcgraw Hill, New Delhi, 1990, 703-715

[18] Z. Xiu-feng, C Yan, H Jiajun, Z Ya-Zhou, N Zhou, T Ya-Lin, LYang, Immunostimulating properties of diosgenyl saponins isolated from Paris polyphylla, Bioorganic and Med. Chem. Letters, 2007

[19] R Srikumar, N.J. Parthasarathy, R Sheeladevi. Immuno modulatory activity of Triphala on Neutrophil Functions, Biol. Pharm. Bull.,2005, 28(8), 1398 - 1403 